\title{
A Solid Phase Pre-Concentration Study Concerning Lornoxicam: A Likely Future Emerging Pollutant
}

\author{
do Nascimento, S. F. L.; da Silva, W. A.; Cabral, T. S.; Pacheco, W. F. *
}

Rev. Virtual Quim., 2019, 11 (4), 1364-1376. Data de publicação na Web: 19 de agosto de 2019

http://rvq.sbq.org.br

\section{Estudo de Pré-Concentração em Fase Sólida do Lornoxicam: Um Provável Futuro Poluente Emergente}

Resumo: Lornoxicam (Lx) é um medicamento antiinflamatório não esteroidal (AINE) pertencente à classe dos oxicams. Esta classe de fármacos está atualmente entre os poluentes ambientais mais comumente detectados, em concentrações que variam da faixa de $\mu \mathrm{g}$ a $\mathrm{n} \mathrm{L}^{-1}$, sendo de grande preocupação devido aos seus potenciais efeitos e impactos nos organismos vivos. Neste contexto, este estudo teve como objetivo desenvolver uma metodologia analítica para quantificar Lx em água de abastecimento. A metodologia compreende uma etapa de pré-concentração do analito através da aplicação da extração em fase sólida (EFS). Neste passo, o cartucho de EFS contendo o sorvente comercializado sob o nome de Strata $X$ foi carregado com até $2 \mathrm{~L}$ de uma solução aquosa de $\mathrm{Lx}$, com massa de $60 \mathrm{mg} / 3 \mathrm{~mL}$, permitindo um fator de concentração de 400 vezes. A quantificação foi realizada por voltametria adsortiva de redissolução no modo de pulso diferencial. A conjugação de voltametria com o método EFS levou a um limite de deteç̧ão de $0,12 \mathrm{\mu g} \mathrm{L}^{-1}$ e um limite de quantificação de $0,40 \mu \mathrm{g} \mathrm{L} \mathrm{L}^{-1}$, com alta seletividade, precisão (<6.0\%) e precisão (recuperação média de 97,60 $\pm 4,10 \%, \mathrm{n}=6$ ). Não foi detectado lornoxicam nas amostras analisadas.

Palavras-chave: NSAID; poluente emergente; abastecimento de água; voltametria.

\begin{abstract}
Lornoxicam (Lx) is a non-steroidal anti-inflammatory drug (NSAID) belonging to the oxicam class. This class of drugs is currently among the most commonly detected environmental pollutants, at concentrations ranging from the $\mu \mathrm{g}$ to $\mathrm{ng} \mathrm{L}^{-1}$ range, of great concern due to their potential effects and impacts on living organisms. In this context, this study aimed to develop an analytical methodology to quantify Lx in the water supply. The methodology comprises a pre-concentration step of the analyte through the application of solid phase extraction (SPE). In this step, an SPE cartridge containing the sorbent marketed under the name strata $\mathrm{X}$ was loaded with up to $2 \mathrm{~L}$ of an aqueous $\mathrm{Lx}$ solution, at a mass of $60 \mathrm{mg} / 3 \mathrm{~mL}$, allowing for a 400 -fold preconcentration factor. Quantification was carried out by adsorptive stripping voltammetry in the differential pulse mode. The conjugation of voltammetry with the SPE method led to a limit of detection $0.12 \mu \mathrm{g} \mathrm{L}^{-1}$ and a limit of quantification of $0.40 \mu \mathrm{g} \mathrm{L}^{-1}$, with high selectivity, precision $(<6.0 \%)$, and accuracy (mean recovery of $97.60 \pm 4.10 \%, n=6)$. No Lx was detected in the analyzed samples.
\end{abstract}

Keywords: NSAID; emerging pollutant; water supply; voltammetry.

\footnotetext{
* Universidade Federal Fluminense, Instituto de Química, Programa de Pós-Graduação em Química, Campus do Valonguinho, CEP 24020-150, Niterói-RJ, Brasil.

$M$ suellenfabricia@id.uff.br DOI: $10.21577 / 1984-6835.20190094$
} 


\section{A Solid Phase Pre-Concentration Study Concerning Lornoxicam: A Likely Future Emerging Pollutant \\ Suéllen F.L. do Nascimento, ${ }^{a}$ Wanderson A. da Silva, ${ }^{b}$ Taíssa da S. Cabral, ${ }^{a}$ Wagner F. Pacheco ${ }^{a, *}$ \\ a Universidade Federal Fluminense, Instituto de Química, Programa de Pós-Graduação em Química, Campus do Valonguinho, CEP 24020-150, Niterói-RJ, Brasil. \\ ${ }^{\text {b } C e n t r o ~ F e d e r a l ~ d e ~ E d u c a c ̧ a ̃ o ~ T e c n o l o ́ g i c a ~ C e l s o ~ S u c k o w ~ d a ~ F o n s e c a ~(C E F E T-R J), ~ C o o r d e n a c ̧ a ̃ o ~}$ de Licenciatura em Física, CEP 25620-003, Petrópolis-RJ, Brasil. \\ * suellenfabricia@id.uff.br}

\section{Introduction}

\section{Material and Methods}

2.1. Chemicals and apparatuses

2.2. Eletrochemical measurements

2.3. Sample preparation extraction study

2.4. Interference study

\section{Results and Discussion}

3.1. Eletrochemical measurements

3.2. Solid Phase Extraction (SPE)

3.3. Study concerning possible interferents

3.4. Lornoxicam determination in water supply samples

\section{Conclusions}

\section{Introduction}

So called Emerging Pollutants are chemicals of day-to-day use, such as pharmaceuticals and cosmetics, disposed of in routine activities (during the bath, or excreted in the toilet, among others). ${ }^{1}$ Due to their inadequate disposal and the ineffectiveness of water treatment protocols, these chemical species can reach water supply reservoirs, and have been detected in potable water at the $\mu \mathrm{g}$ $\mathrm{L}^{-1}$ or $n g \mathrm{~L}^{-1}$ range. ${ }^{2}$ These contaminants may cause adverse ecological and human health effects. $^{3}$ Because of this, increased interest in the development of methodologies capable of monitoring these substances has been noted. Over 700 contaminants have been listed as Emerging Pollutants. ${ }^{3}$

Nadais et $a l^{4}$ pointed out that many studies have demonstrated that several non-steroidal anti-inflammatory drug (NSAIDs) are present 
in local effluent pollutants, and that they may persist even after wastewater treatment. Several factors, such as physical-chemical characteristics, incomplete body elimination and conventional wastewater treatment, lead to increasing NSAID environmental risks. The main side effects presented by this class of drugs are due to the inhibition of the cyclooxygenase enzyme, leading to gastrointestinal, renal and cardiovascular complications. Continued release of NSAIDs into the environment may cause unexpected adverse effects on both terrestrial and aquatic ecosystems, compromising human and biota health. ${ }^{5}$ Currently, this class is among the most commonly detected pollutants in the environment, of great concern due to their potential effects and impacts on living organisms.

Pugajeva et a $l^{6}$ developed a method for the determination of 24 emerging contaminants in wastewater in the city of Riga, Latvia. The method involved solid phase extraction conjugated with high performance liquid chromatography coupled to a hybrid quadrupole. The NSAID ibuprofen was found at a concentration range of $100-325 \mathrm{ng} \mathrm{L}^{-1}$, one of the highest concentrations among the evaluated contaminants.

Manzo et $a l^{7}{ }^{7}$ through a new solid phase microextraction methodology, determined six NSAIDs (Ibuprofen, Acetylsalicylic acid, Naproxen, Ketoprofen, Mefenamic acid and Diclofenac) in both influents and effluents from wastewater treatment plants in Santiago, Chile. The concentrations of the detected drugs ranged from 1.5 to $13.4 \mu \mathrm{g} \mathrm{L}^{-1}$ and 1.0 to $3.2 \mathrm{\mu g} \mathrm{L}^{-1}$ in the influents and effluents, respectively.

Paíga et $a l^{8}$ detected NSAIDs in seawater samples from the Atlantic Ocean off the Northern Portuguese coast. The employed analytical method was based on off-line solidphase extraction and ultra-high performance liquid chromatography coupled to tandem mass spectrometry. The authors emphasized that ibuprofen, hydroxybuprofen and ketoprofen displayed a frequency of detection of $100 \%$ in all samples obtained on different days, at concentrations up to a few hundred $n g L^{-1}$.

A good way to scale the worldwide consumption of NSAIDS is by looking at the sales of this class, that corresponds up to $10 \%$ of all drugs prescribed annually. ${ }^{9}$ Lornoxicam (Lx) (Figure 1) is a NSAID belonging to the oxicam class. It displays anti-inflammatory, antipyretic and analgesic actions due to the inhibition of cyclooxygenase. ${ }^{10}$ Its half live of 3-5 hours and it displays a water solubility of $0.43 \mathrm{mg} \mathrm{mL}$, similar to other species classified as emerging pollutants. ${ }^{11}$ Lornoxicam is prescribed for moderate to severe pain, in which it has the main advantage over other NSAIDs, due to its longer effects. ${ }^{12}$ Therefore, as a consequence of its intrinsic activities and the fact that it is still an unregulated contaminant, Lx may be classified in a near future as an emerging pollutant in aquatic environments. ${ }^{7}$ However, no information on its determination in environmental samples or water supply is available.

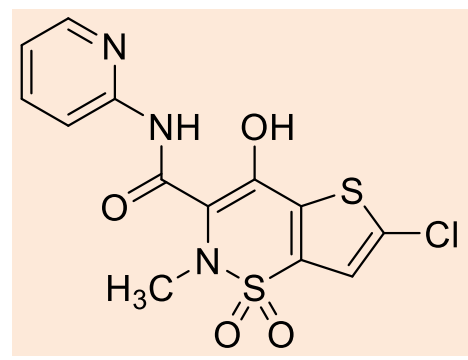

Figure 1: Chemical structures of lornoxicam. ${ }^{13}$

Some studies have described matrices such as blood plasma, methodologies for Lx quantification in several pharmaceutical formulations and synovial 
fluid, through different techniques, including ultraviolet-visible absorption spectroscopy, ${ }^{14,15}$ liquid chromatography, ${ }^{16}$ micellar liquid chromatography. ${ }^{17}$ The most commonly applied is reverse phase liquid chromatography. ${ }^{17}$ Some studies have applied voltammetry in this regard, to detect lornoxicam in pharmaceutical formulations and blood plasma. ${ }^{18,19}$ However, no studies on Lx determinations in water supply or environmental matrices are available. In addition, none of the aforementioned methodologies reach the limits of quantification required for this purpose.

In this context, due to the pollutant potential of $L x$, the development of new methodologies for its determination in the water supply is of significant environmental interest. Therefore, the present study aims to develop an analytical methodology to quantify lornoxicam in the water supply, through voltammetry, due to the low-costs, speed and robustness of this technique. Due to expected low concentrations and the presence of potential interferents in environmental samples, solid phase extraction (SPE) was applied for sample pre-concentration.

\section{Material and Methods}

\subsection{Chemicals and apparatuses}

All aqueous solutions were prepared with ultrapure water $(18 \mathrm{M} \Omega \mathrm{cm})$ obtained on a SatoriusArium $^{\circledR}$ pro-ultra purifier system. Nitric acid $\left(\mathrm{HNO}_{3}\right)$ and glacial acetic acid $\left(\mathrm{CH}_{3} \mathrm{COOH}\right)$ were purchased from VETEC, hydrochloric acid $(\mathrm{HCl})$, ortho-phosphoric $\left(\mathrm{H}_{3} \mathrm{PO}_{4}\right)$, boric acid $\left(\mathrm{H}_{3} \mathrm{BO}_{3}\right)$ and sulfuric acid $\left(\mathrm{H}_{2} \mathrm{SO}_{4}\right)$ were obtained from Merck, and acetonitrile $\left(\mathrm{CH}_{3} \mathrm{CN}\right)$ was obtained from J.T. Baker.

Britton Robbinson $0.04 \mathrm{~mol} \mathrm{~L}^{-1}$ Buffer was prepared by mixing $0.04 \mathrm{~mol} \mathrm{~L}^{-1}$ of glacial acetic acid, ortho-phosphoric acid and boric acid, followed by the addition of $1 \mathrm{~mol} \mathrm{~L}^{-1}$ of sodium hydroxide $(\mathrm{NaOH})$ until the desired $\mathrm{pH}$ value was reached.

A $900 \mathrm{mg} \mathrm{L}^{-1}$ stock solution of lornoxicam was prepared in acetonitrile, while the working solution of $180 \mathrm{mg} \mathrm{L}^{-1}$ was prepared from this stock solution, at a final constitution of $20 \%$ acetonitrile and $80 \%$ of the support electrolyte.

The water supply samples were obtained in the city of Niteroi, state of Rio de Janeiro, Brazil. For the accuracy test, Lx was added to two aliquots of each sample at 30.0 and $4.0 \mu \mathrm{g}$ $\mathrm{L}^{-1}$.

Voltammetric measurements were carried out using a Metrohm model 747 VA voltammetric analyzer, with a carbon vitreous working electrode and $\mathrm{Ag} \mid \mathrm{AgCl}$ (sat) and platinum reference and auxiliary electrodes, respectively. The working cells $50 \mathrm{~mL}$ capacity borosilicate cells.

For the SPE step, a Phenomenex manifold coupled to a vacuum pump for 12 simultaneous samples was used. A model USC 1450 ultrasound bath (Unique) was used for the preparation and homogenization of the standard solutions.

\subsection{Electrochemical measurements}

Before each series of electrochemical measurements the vitreous carbon electrode was subjected to an adapted cleaning procedure. $^{20}$ Initially, the electrode was subjected to a polishing process with alumina powder $(0.30 \mu \mathrm{m}$ to $0.05 \mu \mathrm{m})$, followed by cleaning in an ultrasonic bath for 10 minutes in an alumina and distilled water dispersion. Finally, the electrode was electrochemically activated by cyclic voltammetry in an $0.1 \mathrm{~mol}$ $\mathrm{L}^{-1} \mathrm{H}_{2} \mathrm{SO}_{4}$ solution for 30 cycles from -1.4 to 1.4 $\mathrm{V}$.

The voltammetric parameters were optimized in an univariate way for differential pulse voltammetry, with optimal results as follows: signal measurement $0.724 \mathrm{~V}$, deposition potential $0.05 \mathrm{~V}$, deposition time 
$50 \mathrm{~s}$, amplitude $0.05 \mathrm{~V}, 0.01 \mathrm{~s}$ pulse time 0.01 $\mathrm{s}$, step potential time $0.1 \mathrm{~s}$, step potential 0.01 $\mathrm{V}$, supporting electrolyte: $\mathrm{H}_{2} \mathrm{SO}_{4} 0.01 \mathrm{~mol} \mathrm{~L}$ $1 /$ acetonitrile $(80 / 20)$.

\subsection{Sample preparation extraction study}

The evaluated solid phases were the following commercial cartridges: Sep-pak plus CN (Waters), Strata-X (Phenomenex), Oasis HLB-Plus (Waters) and Sep-pak plus C18 (Waters). The cartridges were conditioned and washed with $1 \mathrm{~mL}$ of water and during the SPE optimization studies, the loading step was always performed with $5.0 \mathrm{~mL}$ of lornoxicam at $40 \mathrm{mg} \mathrm{L}^{-1}$ in an aqueous solution. For the eluent study, solvents acetonitrile $\left(\mathrm{CH}_{3} \mathrm{CN}\right)$, methanol $\left(\mathrm{CH}_{3} \mathrm{OH}\right)$, n-hexane $\left(\mathrm{C}_{6} \mathrm{H}_{14}\right)$, hydrochloric acid $(\mathrm{HCl})$ and $0.01 \mathrm{~mol} \mathrm{~L}^{-1}$ of sodium hydroxide $(\mathrm{NaOH})$ were tested and performed with $3.0 \mathrm{~mL}$.

Breakthrough curves were constructed to evaluate lornoxicam sorption capacity after optimization of the SPE conditions. These curves were prepared by eluting $1.0 \mathrm{~L}$ of aqueous lornoxicam solutions at $0.5,1.0$ and $6.0 \mathrm{mg} \mathrm{L}^{-1}$.

\subsection{Interference study}

To test the interferences of other possible emerging pollutants in the water, a lornoxicam solution containing Ibuprofen, potassium diclofenac, mefenamic acid and indomethacin (all from Sigma Aldrich) were used, all at a final concentration of $30 \mu \mathrm{g} \mathrm{L}^{-1}$, was prepared, and the SPE procedure was performed under optimized conditions.

\section{Results and Discussion}

\subsection{Electrochemical measurements}

3.1.1. Instrumental conditions and analytical parameters of merit

Lornoxicam detection was carried out by adsorptive stripping voltammetry on a vitreous carbon electrode. The instrumental conditions were optimized using as starting point the study published by Bozal. ${ }^{18}$ Conditions are presented in section 2.2.

Using the aforementioned parameters, limits of detection and quantification of $48 \mu \mathrm{g}$ $\mathrm{L}^{-1}$ and $160 \mu \mathrm{g} \mathrm{L}^{-1}$ were obtained, respectively. The linear range extended to $11.3 \mathrm{mg} \mathrm{L}^{-1}$. The LOD and LOQ values were calculated using equations $3 \mathrm{~S}_{\mathrm{b}} / \mathrm{m}$ and $10 \mathrm{~S}_{\mathrm{b}} / \mathrm{m}$, where $\mathrm{S}_{\mathrm{b}}$ is the standard deviation of 10 blank measures and " $\mathrm{m}$ " is the angular coefficient of the analytical curve. ${ }^{21} \mathrm{~A}$ typical curve presents the equation $I_{p}=1.53 .10^{-07}[L x]+1.00 \cdot 10^{-07}$. The voltammograms used to construct the analytical curve are displayed in Figure 2. 


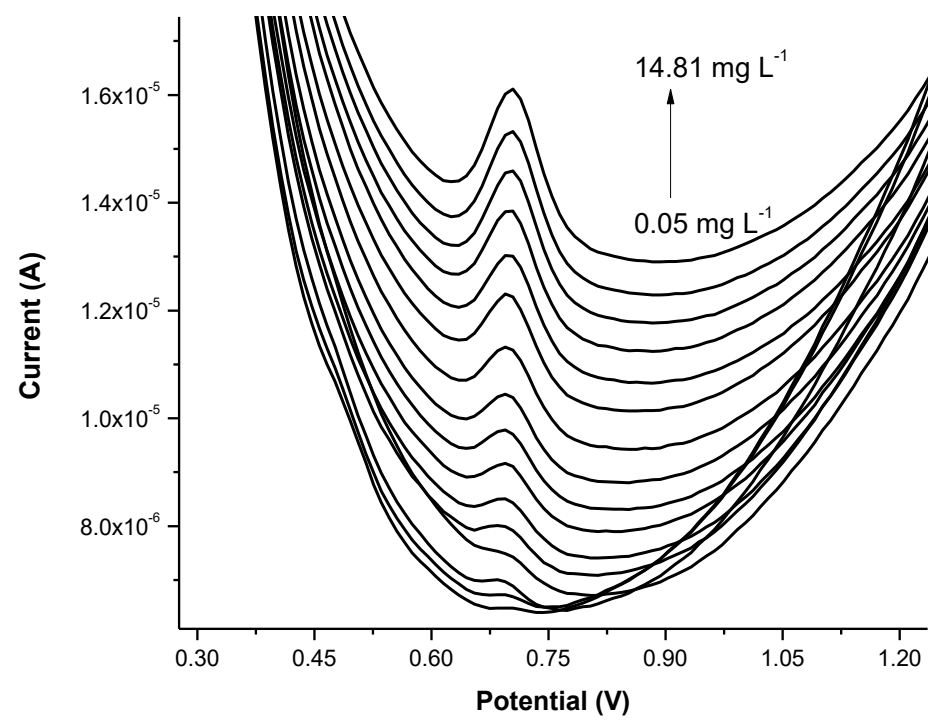

Figure 2. Voltammograms used to obtain a typical analytical curve for lornoxicam

The instrumentally obtained limits are insufficient to apply to real samples containing lornoxicam as an emerging pollutant. Thus, in order to attempt to obtain higher preconcentration factors, the solid phase extraction technique was evaluated.

\subsection{Solid Phase Extraction (SPE)}

A detailed study was carried out on the most relevant parameters for this type of technique, namely type of sorbent, sample $\mathrm{pH}$, nature and volume of the eluent, aiming at maximum preconcentration. Initial screening tests were carried and, subsequently, more specific experiments were carried out to reach satisfactory recovery and precision values for the analyte.

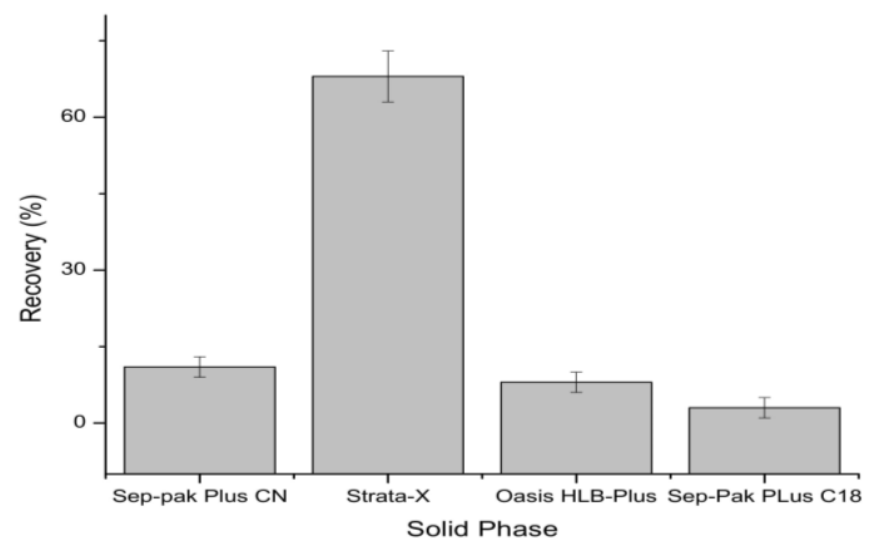

Figure 3. Solid phase study. Experimental conditions: $5.0 \mathrm{~mL}$ loading of a $40 \mathrm{mg} \mathrm{L}^{-1} \mathrm{Lx}$ solution; eluent: $1.5 \mathrm{~mL}$ of acetonitrile; conditioning and washing with $1.0 \mathrm{~mL}$ of water 
The main characteristics of the solid phases chosen to carry out this study are presented in Table 1.

According to results obtained in the solid phase selection study (Figure 3), Strata $x$ was selected, as it presented higher Lx recovery. According to the manufacturer, ${ }^{22}$ this solid phase is a functionalized polymeric sorbent containing $\mathrm{N}$-vinylpyrrolidone and presents three retention mechanisms: $\pi-\pi$ bond, hydrogen bonding and dipole-dipole interaction. All these modes of interaction can occur between the solid phase and the Lx molecule, unlike the other solid phases, which do not present the same retention modes, ${ }^{23,24}$ explaining the greater sorption observed for the Strata- $X$ cartridges, even though it displays lower sorbent mass.

Table 1. Main characteristics of the solid phases studied

\begin{tabular}{cccc}
\hline Solid phase & $\begin{array}{c}\text { Sorbent mass } \\
(\mathbf{m g})\end{array}$ & Lx loading $(\mathbf{m g})$ & Feature chemistry \\
\hline Sep-pakplus CN & 360 & 0.2 & Predominantly Hydrophilic \\
Strata-X & 60 & 0.2 & Hydrophilic and Hydrophobic \\
Oasis HLB-Plus & 360 & 0.2 & Predominantly Hydrophobic \\
$\begin{array}{c}\text { Sep-pakplus C18 } \\
\text { (end-capped) }\end{array}$ & 360 & 0.2 & Predominantly Hydrophobic \\
\hline
\end{tabular}

The data displayed in Figure 4 were obtained as a result of the eluting solvent study. The organic solvents were chosen due to higher Lx solubility in these solvents, and acidic and basic ones were used since $L x$ has an ionic equilibrium (pKa 4.7). ${ }^{25}$ Acetonitrile was the most efficient eluent, removing $100 \%$ $\mathrm{Lx}$ from the solid phase using $5.0 \mathrm{~mL}$. Methanol, $\mathrm{HCl} 0.01 \mathrm{~mol} \mathrm{~L}^{-1}$ and $\mathrm{NaOH} 0.01 \mathrm{~mol}$ $\mathrm{L}^{-1}$ led to low $\mathrm{Lx}$ removal, while $\mathrm{n}$-hexane removed no measurable amounts.

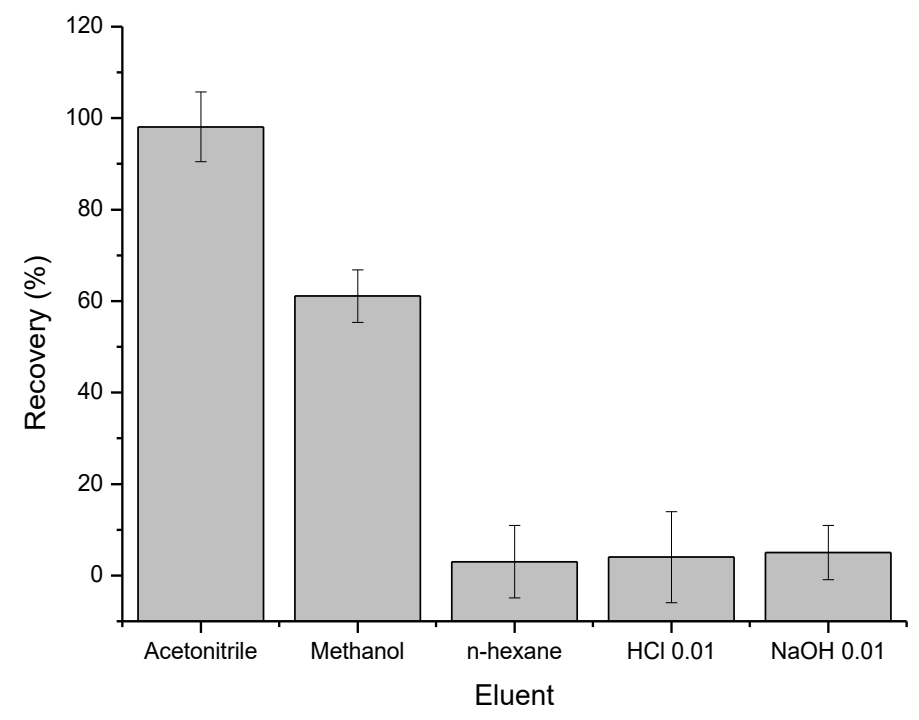

Figure 4. Eluent study. Experimental conditions: $5.0 \mathrm{~mL}$ loading of a $40 \mathrm{mg} \mathrm{L}^{-1} \mathrm{Lx}$ solution; eluent: $3.0 \mathrm{~mL}$ of acetonitrile; conditioning and washing with $1.0 \mathrm{~mL}$ of water 
Determination of the cartridge sorptive capacity was carried out by constructing breakthrough curves, consisting of a plot displaying the charged sample volume versus the ratio of the concentration percolated to the charged concentration $\left(C / C_{0}\right)$. Many authors define a breakthrough curve as the required sample volume to be percolated by the cartridge until an eluate signal equivalent to $1 \%$ of the initial sample $\left(C / C_{0}=0.01\right)$ is obtained. ${ }^{26}$ For this study, different rupture curves were constructed for different $L x$ solutions $\left(6.0,1.0\right.$ and $\left.0.5 \mathrm{mg} \mathrm{L}^{-1}\right)$. The results are displayed in Figure 5.

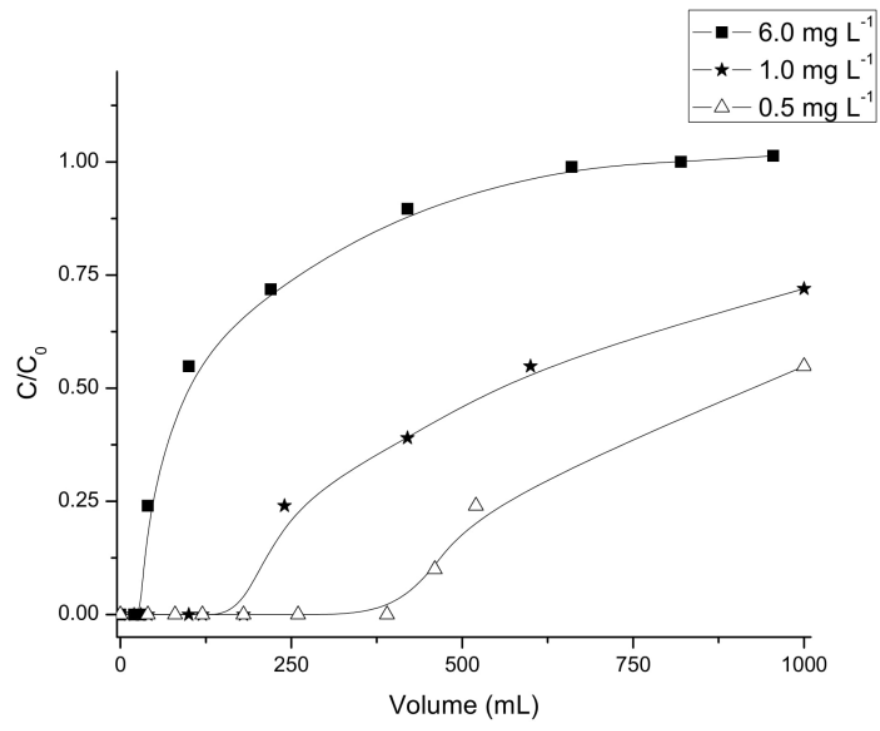

Figure 5. Breakthrough curves obtained for different $L x$ concentrations $\left(6.0,1.0\right.$ and $\left.0.5 \mathrm{mg} \mathrm{L}^{-1}\right)$

Sorption capacity and rupture volume are among the most important parameters in SPE studies, since they determine the maximum mass that can be sorbed by the solid phase mass and the maximum sample volume that the solid phase entails, respectively. ${ }^{27}$ The results of the calculated sorptive capacity for the studies performed and displayed in Figure 4 were the same, of $7.70 \pm 0.40 \mathrm{mg} \mathrm{g}^{-1}$, although for different initial concentration values, different rupture volume values were obtained (35, 200 and $455 \mathrm{~mL})$. As the sample to be applied is relatively simple (water supply) high variations in the sorption capacity are not expected. Higher rupture volume values will be obtained for lower $L x$ concentrations, which would allow for high preconcentration factors.

To test this hypothesis, a study was performed concerning preconcentration efficiency using, different loading solution volumes and concentrations, as well as different elution volumes. The results are presented in Table 2. 
do Nascimento, S. F. L. et al.

Table 2. Preconcentration factor study

\begin{tabular}{ccccc}
\hline $\begin{array}{c}\text { Load } \\
\text { concentration } \\
\left(\mathrm{mg} \mathrm{L}^{-1}\right)\end{array}$ & $\begin{array}{c}\text { Load } \\
\text { volume } \\
(\mathrm{mL})\end{array}$ & $\begin{array}{c}\text { Eluted } \\
\text { volume }(\mathbf{m L})\end{array}$ & Preconcentration factor & Recovery (\%) \\
\hline $\mathbf{4 0 . 0 0}$ & 5 & 1.5 & 3.33 & $67.00 \pm 1.99$ \\
$\mathbf{0 . 4 0}$ & 500 & 3.0 & 166.67 & $88.80 \pm 6.98$ \\
$\mathbf{0 . 0 6}$ & 1000 & 3.0 & 333.33 & $95.83 \pm 5.96$ \\
$\mathbf{0 . 0 3}$ & 2000 & 3.0 & 400.00 & $92.91 \pm 8.00$ \\
$\mathbf{0 . 0 0 4}$ & 2000 & 3.0 & 400.00 & $98.50 \pm 5.03$ \\
\hline
\end{tabular}

For diluted solutions $\left(4 \mu \mathrm{g} \mathrm{L}^{-1}\right)$, a 400 -fold preconcentration factor was obtained, without loss in recovery. As the instrumental limits were $50 \mu \mathrm{g} \mathrm{L}^{-1}$ (LOD) and $160 \mu \mathrm{g} \mathrm{L}^{-1}$ (LOQ), the use of the SPE technique allowed for method limits of $120 \mathrm{ng} \mathrm{L}^{-1}$ and $400 \mathrm{ng} \mathrm{L}^{-1}$, respectively. With this preconcentration factor, the limits of quantification reach what is necessary for emerging pollutants, which normally range from $\mathrm{ng} \mathrm{L}^{-1}$ to $\mu \mathrm{g} \mathrm{L}^{-1}$. However, it was still necessary to test for possible interferences from other emerging pollutants that could be present in the same sample, before applying the method to real samples.

Table 3. Comparison of the LOQ of the methodology proposed herein with other literature methods for ATO quantification

\begin{tabular}{ccccc}
\hline Method & $\begin{array}{c}\text { LOQ } \\
\left(\mathrm{mg} \mathrm{L}^{-1}\right)\end{array}$ & Precision (\%) & Accuaracy (\%) & Reference \\
\hline $\begin{array}{c}\text { Molecular absorption } \\
\text { in the UV-VIS range } \\
\text { LC- MS in Positive lon } \\
\text { Mode }\end{array}$ & $86.9 \mathrm{ng} \mathrm{mL}^{-1}$ & 0.348 & 99.29 & 15 \\
$\begin{array}{c}\text { Voltammetric } \\
\text { LC- MS }\end{array}$ & $17.1 \mathrm{ng} / \mathrm{mL}^{-1}$ & 0.76 a 7.91 & 70.98 & 16 \\
$\begin{array}{c}\text { high-performance } \\
\text { high }\end{array}$ & $6.5 \mathrm{ng} \mathrm{mL}^{-1}$ & 1.0 & 102 & 19 \\
liquid chromatographic \\
SPE + Voltammetric & $5.0 \mathrm{ng} \mathrm{mL}^{-1}$ & 6.4 & 100.2 & 13 \\
\hline
\end{tabular}

As the pre-concentration factor for the proposed method was of 400 , the LOD and LOQ obtained for the determination of lornoxicam after the SPE were 0.12 and 0.40 $\mu \mathrm{g} \mathrm{L^{-1 }}$, respectively. Comparing this with the figure of merits reported for other literature methods (Table 3 ), it is noted that the preconcentration performed with the proposed voltammetric method allowed for better LOQ than some studies, comparable to UV spectrophotometric, chromatographic(LCMS) and other voltammetric methods, making this method extremely promising for LX determination in diluted samples. 


\subsection{Stud interferents}

Ibuprofen, potassium diclofenac mefenamic acid and indomethacin are among the most commonly detected NSAIDs in the environment. Thus, they were tested as possible interferents in aqueous water supply Lx-containing samples and analyzed after SPE. ${ }^{29,30}$ The aqueous solutions containing $L X$ and interferents ibuprofen, potassium diclofenac, mefenamic acid and indomethacin, all in at $30 \mu \mathrm{g} \mathrm{\textrm {L } ^ { - 1 }}$, were submitted to pre-concentration by SPE and analyzed by voltammetry according to the previously presented methodology. A mean recovery of $96.90 \pm 3.90 \%$ was obtained. Figure 6 displays the voltamograms obtained in the construction of the addition curve for $L x$ determination under these conditions.

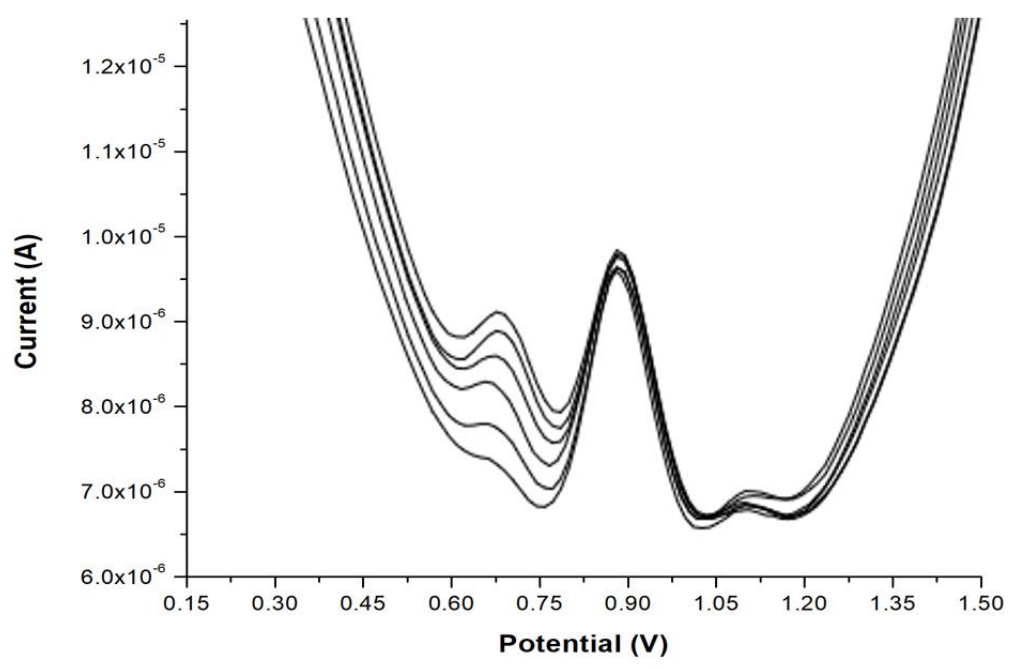

Figure 6. Voltammograms obtained in the interferent study

Ibuprofen showed no current signal peak under the experimental conditions. Diclofenac potassium showed a peak current at $0.873 \mathrm{~V}$, indicating it was not removed in the SPE stage, but did not interfere in the $L x$ determination.

Mefenamic acid showed a current signal peak at $0.843 \mathrm{~V}$ under the experimental conditions, which disappeared after the SPE stage, indicating removal during sample preparation. Indomethacin showed a signal at $1.010 \mathrm{~V}$ under the experimental conditions, which also appeared after the SPE stage, but did not interfere in the Lx quantification.

Therefore, if these NSAIDs are present in the samples also containing Lx, they will not interfere in its quantification, still allowing for the simultaneous identification of diclofenac and indomethacin.

\subsection{Lornoxicam determination in water supply samples}

The method was applied for samples of water supply located at the city of Niterói/RJ (Brazil.) Aliquots of $2.00 \mathrm{~L}$ were taken and submitted to the proposed analytical method. There was no identification of lornoxicam in this samples, indicating that this is not yet an issue in this region. To confirm this result, a recovery test was performed at two different concentrations, 30.0 and $4.0 \mu \mathrm{g} \mathrm{L}^{-1}$.

In this approach, it was made the addition of $L x$ until it reaches this value in each sample, and then it was subjected to the SPE process under optimized conditions, in which its concentration was determined by correlation with an analytical curve prepared. This study 
shows a recovery of $96.7+3.8 \%$ for $30 \mu \mathrm{g} \mathrm{L}^{-1}$ and $98.50 \pm 5.03$ for $4.0 \mu \mathrm{g} \mathrm{L}^{-1}$.

\section{Conclusions}

The method proposed herein was suitable for the determination of the NSAID Lx in water supply samples, with limits of detection and quantification of $120 \mathrm{ng} \mathrm{L}^{-1}$ and $400 \mathrm{ng} \mathrm{L}^{-1}$ and an accuracy of $96.90 \pm 3.90 \%$. The method is also effective in the presence of NSAIDs ibuprofen, potassium diclofenac, mefenamic acid and indomethacin.

Since many NSAIDs, such as ibuprofen and diclofenac, are detected in water supplies and rivers, it is important to monitor other species belonging to the same class. The present study is paramount in filling the knowledge gap concerning $L x$ and in validating a methodology to do so, even if the analyte was not detected in the real sample.

\section{Acknowledgements}

The authors would like to thank FAPERJ and CAPES for financial support and granted scholarships.

\section{References}

${ }^{1}$ Gavrilescu, M; Demnerová, K; Aamand, J; Agathos, S; Fava, F. Emerging pollutants in the environment: present and future challenges in biomonitoring, ecological risks and bioremediation. N Biotechnol 2015, 32, 147. [CrossRef][PubMed]

${ }^{2}$ Geissen, V; Mol, H.; Klumpp, E; Umlauf, G; Nadal, M.; Van der Ploeg, M.; Van de Zee, S.E.A.T.M.; Ritsema, C. J. Emerging pollutants in the environment: A challenge for water resource management. International Soil and Water Conservation Resesearch 2015, 3, 57. [CrossRef]
${ }^{3}$ Dulio, V.; van Bavel, B.; Brorström-Lundén, E.; Harmsen, J.; Hollender, J.; Schlabach, M.; Slobodnik, J.; Thomas, K.; Koschorreck, J. Emerging pollutants in the EU: 10 years of NORMAN in support of environmental policies and regulations. Environmental Sciences Europe 2018, 30, 5. [CrossRef]

${ }^{4}$ Nadais, H.; Li, X.; Alves, N.; Couras, C.; Andersen, H. R.; Angelidaki, I.; Zhang, Y. BioElectro-Fenton process for the degradation of Non-Steroidal Anti-Inflammatory Drugs in wastewater. Chemical Engineering Journal 2018, 338, 401. [CrossRef]

${ }^{5}$ Wang, W.; Xu, Z.; Zhang, X.; Wimmer, A.; Shi, E.; Qin, Y.; Zhao, X.; Zhou, B.; Li, L. Rapid and efficient removal of organic micropollutants from environmental water using a magnetic nanoparticles-attached fluorographenebased sorbent. Chemical Engineering Journal 2018, 343, 61. [CrossRef]

${ }^{6}$ Pugajeva, I.; Rusko, J.; Perkons, I.; Lundanes, E.; Bartkevics, V. Determination of pharmaceutical residues in wastewater using high performance liquid chromatography coupled to quadrupole-Orbitrap mass spectrometry. Journal of Pharmaceutical and Biomedical Analysis 2017, 133, 64. [CrossRef]

${ }^{7}$ Manzo V.; Honda L.; Navarro, O.; Ascar, L.; Richter, P. Microextraction of non-steroidal anti-inflammatory drugs from waste water samples by rotating-disk sorptive extraction. Talanta 2014, 128, 486. [CrossRef]

${ }^{8}$ Paíga, P.; Lolić, A.; Hellebuyck, F.; Santos, L. H. M. L. M.; Correia, M.; Delerue-Matos, C. Development of a SPE-UHPLC-MS/MS methodology for the determination of nonsteroidal anti-inflammatory and analgesic pharmaceuticals in seawater. Journal of Pharmaceutical and Biomedical Analysis 2015, 106, 61. [CrossRef] [PubMed]

${ }^{9}$ Wongrakpanich, S.; Wongrakpanich, A.; Melhado, K.; Rangaswami, J. A Comprehensive Review of Non-Steroidal AntiInflammatory Drug Use in The Elderly. Aging and Disease. 2018, 9, 143. [CrossRef]

${ }^{10}$ Brunton, L. L.; Chabner, B.A.; Knollmann, B.C.; As Bases Farmacológicas da Terapêutica de Goodman and Gilman, 12a. ed., AMGH: 
Porto Alegre, 2012.

${ }^{11}$ Balfour, J. A.; Fitton, A.; Barradell, L. B. Lornoxicam: A Review of its Pharmacology and Therapeutic Potential in the Management of Painful and Inflammatory Conditions. Drugs 1996, 51, 639. [CrossRef]

${ }^{12}$ Karaman, T.; Kuzucuoglu, T.; Arslan, G.; Karaman, S.; Hatun, M. Comparison of the Analgesic Effects of Preemptive Lornoxicam and Paracetamol after Laparoscopic Cholecystectomy. International Journal of Anesthetics and Anesthesiology 2016, 3, 1. [CrossRef]

${ }^{13}$ Suwa, T.; Urano, H.; Shinohara, Y.; Kokatsu, J. Simultaneous high-performance liquid chromatographic determination of lornoxicam and its $5^{\prime}$-hydroxy metabolite in human plasma using electrochemical detection. Journal of Chromatography B: Biomedical Sciences and Applications 1993, 617, 105. [CrossRef] [PubMed]

${ }^{14}$ Annapurna, M. M.; Sushmitha, M.; Sevyatha, V. S. V. New analytical methods for the simultaneous determination of lornoxicam and paracetamol in tablets. International Journal of Pharmacy and Technology 2016, 8, 17535. [Link]

${ }^{15}$ Kondawar, M. S.; Shah, R. R.; Waghmare, J. J.; Shah, N. D.; Malusare, M. K. UV spectrophotometric estimation of paracetamol and lornoxicam in bulk drug and tablet dosage form using multiwavelength method. International Journal of PharmTech Research. 2011, 3, 1603. [Link]

${ }^{16}$ Sahoo, N. K.; Sahu, M.; Rao; P. S.; Ghosh, G. Extraction and Quantification of Lornoxicam in Human Plasma by Liquid ChromatographyTandem Mass Spectrometry in Positive Ion Mode. Asian Journal of Chemistry 2014, 26, 2452. [CrossRef]

${ }^{17}$ El-Shaheny, R. N. Stability-indicating micellar LC methods with time-programmed UV detection for determination of three oxicams in pharmaceuticals with direct injection of gel and suppositories. Journal of Liquid Chromatography \& Related Technologies 2015, 38, 163. [CrossRef]
${ }^{18}$ Bozal, B.; Uslu, B. Applications of Carbon Based Electrodes for Voltammetric Determination of Lornoxicam in Pharmaceutical Dosage Form and Human Serum. Combinatorial Chemistry \& High Throughput Screening 2012, 13, 599. [CrossRef]

${ }^{19}$ Ghoneim, M. M.; Beltagi, A. M.; Radi, A. Square-Wave Adsorptive Stripping Voltammetric Determination of the AntiInflammatory Drug Lornoxicam. Analytical Sciences. 2005, 18, 183. [CrossRef]

${ }^{20}$ Princeton Applied Research Corporation: Application Note, 1979.

${ }^{21}$ Eurachem Guide: The Fitness for Purpose of Analytical Methods - A Laboratory Guide to Method Validation and Related Topics, 2014.

${ }^{22}$ Phenomenex, Simplified Solid Phase Extraction Solutions, 2010. Disponível em: < http://phx.phenomenex.com/lib/br75930712 _w.pdf $>$. Acesso em: 4 janeiro 2019

${ }^{23}$ Oasis, Sample Extration Products. Disponível em: < http://www.waters.com/webassets/cms/libr ary/docs/720005685en.pdf>. Acesso em: 4 janeiro 2019

${ }^{24}$ WATERS. Sample Enrichment and Purification using Solid-Phase Extraction, 2017. Disponível em: < http://www.waters.com/waters/es_ES/SPEMethod-

Development/nav.htm?cid $=10083845$ \&locale =es_ES>. Acesso em: 4 janeiro 2019.

${ }^{25}$ Fang, B. X.; Li, P.; Shi, X. Y.; Chen, F. C.; Wang, L. H. Incompatibilities of lornoxicam with 4 antiemetic medications in polyolefin bags during simulated intravenous administration. Medicine 2016, 95, 1. [CrossRef]

${ }^{26}$ Poole, C. F.; Gunatilleka, A. D.; Sethuraman, R. Contributions of theory to method development in solid-phase extraction. Journal of Chromatography A. 2000, 885, 17. [CrossRef] [PubMed]

${ }^{27}$ Simpson, N. J. K. Solid-Phase Extraction: Principles, Techniques, and Applications. 
Journal of the American Chemical Society. 2000, 122, 12411. [CrossRef]

${ }^{28}$ Shirako, J.; Kawasaki, M.; Komine, K.; Kunisue, Y.; Terada, M.; Sasaki, C.; Irie, W.; Murakami, C.; Tonooka, K.; Tomobe, K.; Shinozuka, T. Simultaneous determination for oxicam non-steroidal anti-inflammatory drugs in human serum by liquid chromatographytandem mass spectrometry. Forensic Science International 2013, 227, 100. [CrossRef] [PubMed]
${ }^{29}$ Wang, J.; He, B.; Yan, D.; Hu, X. Implementing ecopharmacovigilance (EPV) from a pharmacy perspective: A focus on nonsteroidal anti-inflammatory drugs. Science of the Total Environment. 2017, 603, 772. [CrossRef] [PubMed]

${ }^{30}$ aus der Beek, T.; Weber, F. A.; Bergmann, A.; Hickmann, S.; Ebert, I.; Hein, A.; Küster, A. Pharmaceuticals in the environment-Global occurrences and perspectives. Environmental Toxicology and Chemistry. Chem. 2016, 35, 823. [CrossRef] [PubMed] 